\title{
Infrequent, low magnitude HIV-specific T cell responses in HIV-uninfected participants in the $1 \%$ tenofovir microbicide gel trial (CAPRISA004)
}

\author{
WA Burgers ${ }^{1 *}$, TL Muller ${ }^{1}$, A Kiravu', V Naranbhai ${ }^{2}$, S Sibeko ${ }^{2}$, L Werner ${ }^{2}$, Q Abdool Karim² ${ }^{2}$ SS Abdool Karim² \\ From AIDS Vaccine 2012 \\ Boston, MA, USA. 9-12 September 2012
}

\section{Background}

Macaque studies of antiretroviral-containing microbicide gels administered rectally or vaginally followed by SIV challenge have documented priming of SIV-specific $\mathrm{T}$ cell responses in the blood of protected animals. This concept has been termed "chemo-vaccination", where aborted viral replication is thought to leave an immune footprint of exposure, which may augment protection provided by microbicides/PrEP. We investigated whether $\mathrm{T}$ cell responses were detectable in women participating in CAPRISA004 $1 \%$ tenofovir microbicide trial, which showed 39\% efficacy in reducing HIV acquisition.

\section{Methods}

Thirty-eight HIV-uninfected participants were selected based on consistently high gel use and a high number of recorded sex acts over the duration of the trial. Cryopreserved PBMC were stimulated with HIV-1 peptide pools based on the HIV-1 clade C proteome, and IFN-gamma production was measured by the ELISPOT assay. Positive response were defined as $>55 \mathrm{SFU} / 106$ PBMC. Samples were tested at the visit at which preceding monthly coital activity was the participant's highest, and at study exit. Assays were conducted blinded to placebo or tenofovir arm.

\section{Results}

$\mathrm{T}$ cell responses were detected in 1/18 tenofovir and 2/13 placebo participants at the high gel use visit. Responses were of low magnitude (between 60 and 100 SFU/106 PBMC), and directed at peptide pools from HIV Gag, Pol, Nef and Env. T cell responses were not detected at the

${ }^{1}$ University of Cape Town, Cape Town, South Africa

Full list of author information is available at the end of the article exit visit. These data suggest that HIV-specific responses are infrequently detected in blood in uninfected participants from a clinical trial of a vaginal microbicide, and where present, are of low magnitude and transient.

\section{Conclusion}

Magnitude and timing of viral exposure may account for differences in detecting systemic $\mathrm{T}$ cell responses between preclinical studies in non-human primates and a human clinical trial of a vaginal microbicide.

\section{Author details}

${ }^{1}$ University of Cape Town, Cape Town, South Africa. ${ }^{2}$ CAPRISA, Nelson R Mandela School of Medicine, Durban, South Africa.

Published: 13 September 2012

doi:10.1186/1742-4690-9-S2-P225

Cite this article as: Burgers et al:: Infrequent, low magnitude HIV-specific

$T$ cell responses in HIV-uninfected participants in the $1 \%$ tenofovir microbicide gel trial (CAPRISA004). Retrovirology 2012 9(Suppl 2):P225.

Submit your next manuscript to BioMed Central and take full advantage of:

- Convenient online submission

- Thorough peer review

- No space constraints or color figure charges

- Immediate publication on acceptance

- Inclusion in PubMed, CAS, Scopus and Google Scholar

- Research which is freely available for redistribution 